\title{
Recent advances in silage microbiology
}

\author{
Richard E. Muck \\ USDA, Agricultural Research Service, US Dairy Forage Research Center, Madison, Wisconsin, United States \\ e-mail: richard.muck@ars.usda.gov
}

\begin{abstract}
Recent advances in silage microbiology are reviewed. Most new techniques in silage microbiology use the polymerase chain reaction (PCR) to make copies of a portion of the DNA in microorganisms. These techniques allow us to identify and quantify species as well as do community analysis. The PCR-based techniques are uncovering new species, both bacteria and fungi, during storage and feeding. Silage inoculants are widely available, but of greater interest has been research investigating why inoculants are so successful. Various inoculant strains have been found to produce bacteriocins and other compounds that inhibit other bacteria and fungi, improving their chances for success. In vitro ruminal fermentation research is showing that some inoculated silages affect rumen microorganisms, reducing methane in some cases and increasing microbial biomass production in others. Better understanding of silage microbiology will allow us to better manage silos and develop better inoculants to improve silage quality.
\end{abstract}

Key words: lactic acid bacteria, PCR, aerobic stability, inoculants

\section{Introduction}

Recently, dramatic changes have occurred in how we study the microbiology of ensiling. Until about 10 years ago, our knowledge of what occurred in the silo was limited by what would grow on various selective media, and identification of species from those agar plates was tedious work. API 50 strips allowed us to grow strains on 50 different substrates simultaneously. That did speed the identification of lactic acid bacteria, but the strips were not infallible. We struggled to know cause and effect in the silo. Were the acids and other products that we measured during fermentation due to this strain or that strain?

Today, we still have issues with understanding cause and effect in the silo. However, we have much better tools to know which microorganisms have been involved in the ensiling process. We also have a better understanding regarding how microorganisms affect silage quality over beyond production of lactic acid, volatile fatty acids, alcohols and carbon dioxide. In this paper, I will discuss recent developments in the measurements of microbial dynamics during ensiling, our current knowledge of the species that contribute to ensiling as well as the species that spoil silage, the extent to which microbial additives modify fermentation and the utilization of silages by livestock, and efforts to find new microbial additives.

\section{Recent microbial techniques}

The ability to extract microbial DNA from silages, amplify portions of DNA, and then separate those portions by the strains of microorganisms that have produced them has been at the core of the changes that have occurred recently in silage microbiology. These developments have allowed us to enumerate strains that do not grow on agar and reveal new species in silages. These techniques can be divided into two groups: 1) identification and quantification of specific species/strains and 2) community analysis.

\section{Identification and quantification of specific species/strains}

Most of these techniques use the polymerase chain reaction (PCR) to make many copies of a portion of the DNA in microorganisms. The most commonly amplified portion of the DNA from bacteria is the 16S ribosomal RNA gene, which is the primary basis today for classifying bacteria. The PCR primer binding sites for this gene are highly conserved across bacteria while other portions of the $16 \mathrm{~S}$ sequence generally are more variable between species, which permits classification. Some techniques use other portions of the DNA as will be discussed. 
For identification, DNA can be extracted, for example starting from a colony on an agar plate where there is one strain of microorganism present. The $16 \mathrm{~S}$ rRNA gene can be amplified by PCR and then sequenced. Once the sequence is known, a program such as BLAST may be used to compare the sequence of the unknown strain with those of known species. Consequently, one can enumerate lactic acid bacteria or other types by standard plating techniques and then use PCR to identify the species on those plates.

A related technique is real-time PCR (RT-PCR) or quantitative real-time PCR. This analytical technique allows one to quantitate specific species present in a sample. Primers are selected from the region of a gene that is specific to the species of interest. A portion of the 16S rRNA gene has been most commonly used (e.g., Schmidt et al. 2008), but other genes such as the recA gene have been used with lactic acid bacteria (e.g., Stevenson et al. 2006) because it was easier to find sequences to separate species that have very similar 16S rRNA genes. This method is very useful for following species that you expect to be in the environment such as comparing the level of Lactobacillus plantarum in silages that are untreated vs. those inoculated with L. plantarum. Initial studies using RTPCR in silages have compared their primers against other known species to be sure that all known strains of the species of interest react with the primers whereas known strains of other species do not. There still may be species not tested, particularly unknown species, that provide false positives or strains of the species of interest with slight differences in the sequence in the region of the primers causing a false negative. The latter is not a problem if you are following an inoculant strain that reacts with the primers.

Quantification in RT-PCR is based on how many cycles of amplification are needed to reach a target number of copies. The advantage of this technique is that you can enumerate a species that is present at a low level. For example, by standard techniques that begin by picking colonies from an agar plate, one is unlikely to detect a species that is present at less than $1 \%$ of the total population. With RT-PCR, we may be able to enumerate a species that is at $100 \mathrm{cfu} \mathrm{g}^{-1}$ silage even though the total LAB population is $10^{9} \mathrm{cfu}^{-1}$. Thus RT-PCR allows us to follow known species more rapidly and at a much lower detection limit than previously possible.

\section{Community analysis}

Even with PCR and RT-PCR, investigating the effects of various factors on the microbial community in the silo is laborious. Fortunately, a variety of techniques have been developed that allow us to get a snapshot of the bacterial community and then using statistical techniques like principal component analysis to determine if there are significant differences in communities. If there are, then we can use PCR and RT-PCR to document the differences. At least four techniques have been used to study microbial communities in silages: length heterogeneity PCR (LH$P C R$ ), terminal restriction fragment length polymorphism (T-RFLP), denaturing gradient gel electrophoresis (DGGE) and automated ribosomal intergenic spacer analysis (ARISA). All four techniques use PCR to amplify a portion of the microbial DNA and then use various methods to separate the amplified DNA. It is beyond the scope of this paper to discuss these methods in detail. It is more important to know general differences between the techniques.

Length heterogeneity PCR uses the variation in the length of a gene between different microbial species to determine how many species may be active in an environment. Separation of the amplified DNA is by capillary electrophoresis. Brusetti et al. (2006) investigated this technique using the differences in the length of a region of the $16 \mathrm{~S}$ rRNA gene to follow the development of various LAB species during the ensiling of maize. The technique was successful in following most of the species identified in the silages. However, two species identified, Weissella confusa and $W$. kimchii, had identical fragment lengths of 379 base pairs and thus could not be differentiated by LH-PCR. Similarly the Enterobacter species identified had the same fragment lengths. A substantial number of peaks (29-58\%) were not identified.

Terminal restriction fragment length polymorphism operates on a similar principal to LH-PCR. However, a restriction enzyme is added to the amplified DNA cutting it in two. The DNA is separated by either gel or capillary electrophoresis according to the length of the fragments. McEniry et al. (2008) investigated bacterial community dynamics in wilted grass silage using T-RFLP. The 16S rRNA genes were amplified, then digested with the restriction endonuclease $\mathrm{Mspl}$, and separated by electrophoresis. The technique did show that there were shifts in the species with time $(0,2,6,14,35$ and $98 \mathrm{~d})$ and ensiling method (baled vs. precision-chop silage). However, identification of species based on the length of a fragment using a database and simulated digest of the 16S rRNA gene by the restriction enzyme was often not possible because multiple species had the same fragment length. 
In denaturing gradient gel electrophoresis, the movement of each DNA segment is determined by the composition of the nucleotides in the DNA rather than just the length of the DNA sequence. Normally this is used where the amplified DNA is relatively similar in length. For example, Li et al. (2011) amplified the V3 region of the bacterial 16S rRNA gene and the fungal 18S rRNA gene and analysed these by DGGE. An advantage of this procedure was that they could excise prominent bands in the gel and then use PCR techniques/BLAST to identify the species that produced each band.

Automated ribosomal intergenic spacer analysis amplifies the region between the 16S rRNA gene and the 23S rRNA gene in bacteria. Separation is similar to T-RFLP, using fluorescent primers and by fragment length. Brusetti et al. (2008) used both ARISA and LH-PCR to assess bacterial communities in maize silage. ARISA gave 12 peaks on average compared with 9 peaks with LH-PCR, and the range of base pairs was much larger for ARISA. These suggest more sensitivity in the ARISA measurements because the ARISA is amplifying a much more variable region. They used PCR to identify 388 isolates taken from MRS agar plates, falling into 11 known species. However, no attempt was made to match these isolates with the peaks from either ARISA or LH-PCR. So the authors were not able to determine which community method was more accurate in describing differences between silages.

All of the community techniques allow a relatively rapid comparison of communities between treatments. Of the three techniques that separate by length of DNA (LH-PCR, T-RFLP and ARISA), it would appear that ARISA is the least likely to have multiple species with fragments of the same length due to the heterogeneity of the intergenic spacer region in bacteria. However, it is possible for a strain to produce more than one peak in ARISA so that community diversity may appear greater than it is. Because DGGE is performed by gel electrophoresis, the results are more qualitative and variable from one gel to the next compared with using capillary electrophoresis in the other three techniques, where their results are easily imported into statistical software for principal component analyses, etc. On the other hand, DGGE has the advantage mentioned earlier that bands can be excised and cloned by PCR for species identification.

\section{New microbial species in silage}

These new techniques have made it possible to more easily find new species and understand the dynamics of the microbial populations with time in the silo. However, these new techniques have often verified that the traditional species associated with ensiling are the predominant species. Species that have been recently isolated in silages are summarised in Table 1. Specifics about these species are as follows. Brusetti et al. (2006) using LH-PCR reported the presence of Bacillus megaterium early in the ensiling of maize (day 0 and 1 ), Weissella kimchii (d 6 ) and Enterococcus flavescens ( $d$ 13). While these species had not been reported in silage, other more common species dominated the silages. Rossi and Dellaglio (2007) surveyed farm silages, primarily lucerne, maize and Italian ryegrass as well as mixtures of maize silage and maize grain. The LAB isolates matched known silage species with the exception of Lactobacillus zeae. Anaerobic spore formers found were largely known silage clostridial species with the exception of Clostridium baratii and Paenibacillus macerans. Three yeasts species were identified: Candida mesenterica, Candida apicola and Pichia fermentans. This was the first report of the two Candida species in silages even though other Candida species are commonly found in silage.

Several new species have been isolated from silage and had names proposed. These include Lactobacillus taiwanensis (Wang et al. 2009) and Pediococcus lolii (Doi et al. 2009).

Parvin et al. (2010) analysed laboratory silages made with Italian ryegrass, maize, guinea grass and rhodes grass ensiled with and without L. plantarum or Lactobacillus brevis inoculants. DGGE analysis followed by cloning and sequencing of prominent bands found mostly well known silage species. However, the untreated Italian ryegrass had 6 prominent bands, all but one (L. plantarum) was unusual: Pediococcus dextrinicus, Paralactobacillus selangorensis, Burkholderia spp., Serratia spp. and an uncultured bacterium.

Pang et al. (2011b) identified strains isolated from maize stover, and $86 \%$ of the LAB consisted of $L$. plantarum, Lactobacillus pentosus and $L$. brevis, three species commonly reported in silages. On the other hand they reported the presence of Leuconostoc lactis, Enterococcus mundtii and Weissella cibaria, the latter a recently described species. The same group isolated LAB strains from maize, rice, sorghum and lucerne silages (Pang et al. 2011a) and found that $W$. cibaria and Weissella confusa were the dominant species observed in maize silage. In the other silages, L. plantarum was the dominant species. 
Table 1. Microbial species recently isolated from silages

\begin{tabular}{|c|c|c|}
\hline Species & Silage Type & Reference \\
\hline \multicolumn{3}{|l|}{ Lactic Acid Bacteria } \\
\hline Enterococcus flavescens & Maize & Brusetti et al. (2006) \\
\hline Entercoccus mundti & Maize Stover & Pang et al. (2011b) \\
\hline Lactobacillus acetotolerans & Maize & Li and Nishino (2011b) \\
\hline Lactobacillus panis & Maize & Li and Nishino (2011b) \\
\hline Lactobacillus reuteri & Maize & Li and Nishino (2011b) \\
\hline Lactobacillus taiwanensis & Unknown & Wang et al. (2009) \\
\hline Lactobacillus zeae & Lucerne & Rossi and Dellaglio (2007) \\
\hline Leuconostoc lactis & Maize Stover & Pang et al. (2011b) \\
\hline Paralactobacillus selangorensis & Italian Ryegrass & Parvin et al. (2010) \\
\hline Pediococus dextrinicus & Italian Ryegrass & Parvin et al. (2010) \\
\hline Pediococcus lolii & Ryegrass & Doi et al. (2009) \\
\hline Pediococcus parvulus & Maize & Li et al. (2011) \\
\hline Weissella cibaria & Maize, Maize Stover & Pang et al. $(2011 a, b)$ \\
\hline Weissella kimchii & Maize & Brusetti et al. (2006) \\
\hline Weissella paramesenteriodes & Maize & Li et al. (2011) \\
\hline \multicolumn{3}{|l|}{ Anaerobic Spore Formers } \\
\hline Clostridium baratii & Maize & Rossi and Dellaglio (2007) \\
\hline Paenibacillus macerans & Maize & Rossi and Dellaglio (2007) \\
\hline \multicolumn{3}{|l|}{ Bacillus } \\
\hline Bacillus megaterium & Maize & Brusetti et al. (2006) \\
\hline \multicolumn{3}{|l|}{ Enterobacteria } \\
\hline Erwinia persicina & Italian Ryegrass & Li and Nishino (2011a) \\
\hline Pantoea agglomerans & Italian Ryegrass & Li and Nishino (2011a) \\
\hline Rahnella aquatilis & Italian Ryegrass & Li and Nishino (2011a) \\
\hline \multicolumn{3}{|l|}{ Acetic Acid Bacteria } \\
\hline Acetobacter pasteurianus & Maize & Li and Nishino (2011b) \\
\hline \multicolumn{3}{|l|}{ Yeasts } \\
\hline Candida apicola & Maize, Italian Ryegrass & Rossi and Dellaglio (2007) \\
\hline Candida intermedia & Maize & Li et al. (2011) \\
\hline Candida glabrata & Maize & Li et al. (2011) \\
\hline Candida magnolia & Maize & Li et al. (2011) \\
\hline Candida mesenterica & Maize & Rossi and Dellaglio (2007) \\
\hline Candida quercitrusa & Maize & Li et al. (2011) \\
\hline Saccharomyces martiniae & Maize & Li et al. (2011) \\
\hline Pichia deserticola & Maize & Li et al. (2011) \\
\hline Pichia fermentans & Maize & Rossi and Dellaglio (2007) \\
\hline Pichia kudriavzevii & Maize & Li et al. (2011) \\
\hline
\end{tabular}

Li et al. (2011) using DGGE identified the dominant bacterial and fungal species in maize silage. Pre-ensiling and later in the silage, L. brevis, Pediococcus parvulus, W. confusa and Klebsiella pneumoniae were reported. Additionally in the silage, Weissella paramesenteriodes, L. plantarum and Lactobacillus lactis were observed. Yeasts in pre-ensiled maize and maize silage were predominantly Candida species and Cryptococcus flavus. However, the Candida species they reported (magnolia, intermedia, glabrata and quercitrusa) have not been found previously in silages. When the maize silages were subjected to aerobic exposure, Saccharomyces and Pichia species appeared, genuses commonly found in silage, but some of the species were newly reported as being in silages $(S$. martiniae, P. deserticola, P. kudriavzevii).

Li and Nishino (2011b) sampled maize silage from bunker silos. They detected a number of uncommon silage LAB species, Lactobacillus acetotolerans, Lactobacillus panis and Lactobacillus reuteri, as well as other new species in silages: Acetobacter pasteurianus, Stenotrophomonas maltophilia, an Acinetobacter species and a Rahnella species. Li and Nishino (2011a) studied wilted Italian ryegrass silages in mini-silos, finding enterobacteria such as Erwinia persicina, Pantoea agglomerans and Rahnella aquatilis in untreated silages. Known LAB species accounted for the majority of the other species detected. 
Overall, these studies have indicated that the new PCR based techniques are uncovering some new species. In most cases, traditional silage LAB species have been the dominant bacterial species present. However, we still have a difficult time knowing how significant the new species are to silage preservation because these PCR methods do not indicate the contribution of the various species to the overall fermentation. If we could isolate any of the newly detected species, grow it and inoculate silage with it, we could have an insight of its role/effect on silage fermentation.

\section{Effects of various factors on silage microbial populations}

The new techniques have also been useful to study how various factors affect fermentation. The most common factor is the use of a bacterial inoculant, which will be discussed later. However, there have been a few recent studies that have investigated the effects of other factors on the course of fermentation.

McEniry et al. (2010) compared the microbial community in perennial ryegrass in baled vs. precision chop ensiling at two DM concentrations (185 and $406 \mathrm{~g} \mathrm{DM} \mathrm{kg}^{-1}$ ) over 0 to $14 \mathrm{~d}$ using T-RFLP. Using a T-RFLP database, they assigned fragment lengths they observed to general groups, e.g., LAB, enterobacteria, etc. The most abundant fragment was associated with enterobacteria and was most prevalent early in ensiling and in the drier silages whereas the most prevalent fragments associated with LAB behaved in an opposite direction with those two factors. Only three minor species were affected by the ensiling system. In a second experiment, unchopped, unwilted perennial ryegrass was ensiled with or without compaction and with and without air infiltration for $100 \mathrm{~d}$. For the top 20 fragments, most were not affected by either compaction or air infiltration. Six fragments were affected by compaction, having a negative effect on LAB and enterobacteria and a positive effect on clostridia. Only 4 fragments were affected by air infiltration: two Clostridium negatively, and one Clostridium and one Bacillus species each positively.

Naoki and Yuji (2008) compared the microbial community in vacuum-packed bag Italian ryegrass silage with wrapped bale silage using DGGE. Specific bands were not excised and identified, but the band pattern in the outer portions of one bale was similar to the pattern in the vacuum-bag silage. However, there were differences in microbial community between bales and locations within a bale, suggesting field variability was affecting, in part, the dominant species.

Brusetti et al. (2006) investigated the usefulness of LH-PCR by following the progression of fermentation in maize silage up to $30 \mathrm{~d}$. Pediococcus pentosaceus and $W$. confusa were the most prevalent species present at ensiling. Both species were present throughout the $30 \mathrm{~d}$. Lactococcus lactis subsp. lactis was also present at ensiling, reaching its highest level at $6 \mathrm{~d}$. Lactobacillus species were reported at various times during the course of the $30 \mathrm{~d}$ : $L$. plantarum, minor levels throughout; L. brevis, d 6-30; L. paraplantarum, d 13, d 20.

Parvin and Nishino (2009) used DGGE to study microbial changes with storage time (15 to 180 d) from the ensiling of guinea grass at two DM concentrations $\left(286,443 \mathrm{~g} \mathrm{~kg}^{-1}\right)$. In the wetter silage, Lactococcus lactis and L. brevis were the dominant species at $15 \mathrm{~d}$ but by $180 \mathrm{~d}$, Lc. lactis was a faint band and L. pentosus was more prevalent. This shift coincided with a reduction in lactate to acetate ratio in the silage with time. In the drier silage, two strains of $L$. plantarum were observed in addition to Lc. lactis and L. brevis. The Lc. lactis band did not diminish with time, but an L. pentosus band did appear at later time points. In the drier silage, lactate to acetate ratio did not change with time, but both acids increased with time.

Parvin and Nishino (2010) measured the changes in microbial community with storage time (15 to 180 d) in rhodes grass silage using DGGE, and prominent bands were sequenced. L. brevis, L. plantarum and L. pentosus were present at all time points although the $L$. plantarum strain in the early time points appeared to be a different strain than that at later times. Lactococcus lactis had a strong band at $15 \mathrm{~d}$ that became fainter with each succeeding time point. There was a faint band of Escherichia coli through $90 \mathrm{~d}$.

Ávila et al. (2010) investigated microbial population changes in 5 cultivars of sugarcane silage at 10, 20, 30 and $40 \mathrm{~d}$. Of particular interest were the yeast populations that varied by cultivar and time. For 3 cultivars, the highest yeast counts occurred at $10 \mathrm{~d}$ with yeast counts being significantly lower at $40 \mathrm{~d}$. For the other 2 cultivars, the highest yeast counts occurred at $30 \mathrm{~d}$ with counts dropping significantly at $40 \mathrm{~d}$. Colonies were picked, and identified by PCR techniques. Of the culturable yeasts, only 4 species were present in the $10 \mathrm{~d}$ silages (Torulaspora delbrueckii, Pichia anomala, Saccharomyces cerevisiae and Candida glabrata), which were the dominant species across all time points. Five other species were identified. The sugarcane cultivars varied in the yeast species observed: one cultivar with just two species (Torulaspora delbrueckii, Pichia anomala), three with five species of yeast, and one with seven species of yeast. 
Villa et al. (2010) compared the ensiling of two maize varieties, one grown in a warm climate and one grown in a cool climate in Colombia. The maize from the warm climate had a higher initial count of LAB, leading to a more rapid decline in $\mathrm{pH}$. The fermentation of the cool climate variety was dominated by Lactobacillus and Pediococcus species with populations of both genuses peaking upon reaching pH 3.8 at $7 \mathrm{~d}$. In the warm climate variety, both genuses peaked at $2 \mathrm{~d}$ when the $\mathrm{pH}$ was below 4.0, but Leuconostoc species also contributed, peaking at 5 $\mathrm{d}$ when $\mathrm{pH}$ had reached 3.7 .

The dynamics of microbial groups in Danish stack silos of maize silages were observed every other month beginning in January and continuing until September (Storm et al. 2010). Yeasts and lactic acid bacteria declined with time over this period whereas moulds were highest in the March and May sample periods. The filamentous fungi were identified and the primary species found were Penicillium roqueforti, Zygomycetes (primarily Mucor spp.), Penicillium paneum and Aspergillus fumigatus. The percentage of stack silos with these species was highest either in March or May. By September, there was a greater diversity across the 20 silos.

Several recent studies have investigated the effects of low temperature on ensiling. They have not used PCR or other sophisticated techniques, but their results are of interest. Wang et al. (2011) ensiled reed grass at 0 and 4 ${ }^{\circ} \mathrm{C}$ and sampled at weekly intervals from 3 to 8 weeks. By week 5, pH had decreased significantly at both temperatures. At week 5 , the $\mathrm{pH}$ was 4.20 in the silage at $4{ }^{\circ} \mathrm{C}$, significantly lower than the silage at $0{ }^{\circ} \mathrm{C}$. Also acetic acid was lower and lactic acid higher at $4^{\circ} \mathrm{C}$. Pauly and Spörndly (2011) investigated maize silage made at 6, 12 and 18 ${ }^{\circ} \mathrm{C}$ in the first year and $2.6,6,12$ and $20^{\circ} \mathrm{C}$ in the second year. The $\mathrm{pH}$ was below 4.0 by $20 \mathrm{~d}$ in the two warmest temperatures. Fermentation at $6{ }^{\circ} \mathrm{C}$ appeared to have stabilized by $60 \mathrm{~d}$ at a pH of 4.1 in both years with a fermentation that was lower in lactic and acetic acids and higher in ethanol than the fermentations at warmer temperatures. When some of the silages stored at $6{ }^{\circ} \mathrm{C}$ were raised to $18{ }^{\circ} \mathrm{C}$ after $45 \mathrm{~d}$ and stored for an additional 61 $\mathrm{d}$, more fermentation occurred reducing $\mathrm{pH}$ similar to that of the $18{ }^{\circ} \mathrm{C}$ silages but with higher concentrations of lactic acid, acetic acid and ethanol than the $18^{\circ} \mathrm{C}$ treatments.

Drawing general conclusions across these studies is difficult. It would appear that type of silo (even field-scale vs. laboratory) or density has only small effects on the dominant species during ensiling. There are considerable differences in the dominant species from one trial to the next, but in most studies, common Lactobacillus, Pediococcus and Lactococcus species were the most prevalent. The biggest deviation appeared to be in maize silage in warm climates where Weissella and Leuconostoc species contributed to early stages of fermentation. Finally, silage fermentation can occur at near freezing temperatures, but active fermentation continues over weeks, not days.

\section{Aerobic deterioration of silage}

When oxygen is introduced to silage, aerobic microorganisms begin to grow, initially respiring soluble substrates and then more complex compounds. This reduces the digestibility and feeding value of silage. The general pattern of spoilage has been known for approximately two decades. Yeasts are generally the initiators of aerobic deterioration, consuming sugars and fermentation acids and raising silage temperature and pH (Pahlow et al. 2003). With increased $\mathrm{pH}$, bacilli and other aerobic bacteria grow, increasing temperature further. Finally, moulds complete the deterioration of the silage. In maize silage, acetic acid bacteria have been found to be initiators of aerobic deterioration in some cases.

Much of the recent work on aerobic deterioration has been in the study of inoculants to inhibit the rate of spoilage. However, there are a number of recent studies that contribute to our understanding of microbial dynamics in spoiling silages. Dolci et al. (2011) studied microbial dynamics during aerobic exposure of inoculated (L. buchneri, L. plantarum, E. faecium) maize silages stored in polyethylene or oxygen barrier film bags for $110 \mathrm{~d}$. The latter had a permeability to oxygen that was $5 \%$ of that of the polyethylene film. The silages were sampled 6 times between opening and $14 \mathrm{~d}$ of aerobic exposure. DGGE was used to study both the bacterial and fungal communities, and prominent bands were excised and cloned for identification of species. At opening, bands identified as $L$. buchneri were dominant in both treatments. With aerobic exposure, the $L$. buchneri band diminished within one week in the polyethylene treatment where the silage began to heat in $3 \mathrm{~d}$. At day 5 and continuing through day 14, the dominant band in that treatment belonged to Acetobacter pasteurianus, and a fainter band identified as Bacillus subtilis was present. In the silage made with the oxygen barrier film, these species did not appear until day 9 and 14, respectively, where heating did not begin until 9 days. The two fungal species present at opening (Kazachstania exigua, Aureobasidium pullulans) were unusual species for silages. Both bands disappeared after 5 days in the polyethylene treatment. Later Pichia kudriavzevii and Aspergillus fumigatus appeared in the poly- 
ethylene treatment whereas $A$. fumigatus and an unknown species appeared in the oxygen barrier film treatment. The unknown species appeared tied to the beginning of heating, being the dominant band at $9 \mathrm{~d}$. Overall, it is interesting that in the film with higher oxygen permeability it appeared that Acetobacter was the initiator of aerobic deterioration whereas an unknown fungal species initiated spoilage in the other treatment. Bacillus and mould species became more prevalent after heating and increases in $\mathrm{pH}$ had occurred, as expected.

Borreani and Tabacco (2010) cored the faces of 54 maize silage bunker silos measuring fermentation products, yeasts, moulds, clostridial spores and also taking temperatures at $200 \mathrm{~mm}$ behind the feed out face. At least 18 core samples were taken from each silo spanning the width and height of each bunker. They compared these temperatures with the temperature in the middle of the face at $400 \mathrm{~mm}$ depth, where temperature is relatively constant, similar to temperatures deeper in the bunker. The $200 \mathrm{~mm}$ temperature at a specific location minus the temperature at $400 \mathrm{~mm}$ in the middle of the bunker was positively correlated with $\mathrm{pH}$, yeast and mould counts. This suggests that temperature measurements at the farm could be used to rapidly estimate fungal counts and assess the aerobic stability of silage. This survey was done in northern Italy. It would be interesting to know if differences in silage temperature will be a good predictor of fungal counts in more severe climates.

Tabacco et al. (2011) surveyed 42 farm silos with maize silage, half of them treated with an L. buchneri inoculant. Aerobic stability was negatively related to yeast count, and it appeared that improved aerobic stability in the inoculated silages was due to the reduction in yeast count. Pearson correlation coefficients between yeast count and various chemical and management variables indicated the strongest relationship was a negative correlation with feed out rate $(-0.579)$. Also highly correlated $(p<0.01)$ with yeast count were lactic acid $(0.549), \mathrm{pH}(-0.456)$, silo DM density $(-0.451)$ and lactic-to-acetic acid ratio (0.437). Acetic acid was correlated at $p<0.05(-0.331)$. These results confirm that in the real world susceptibility to aerobic losses is a function of both the fermentation in the silo and management factors (density and feed out rate) that influence the exposure of the silage to oxygen prior to removal from the silo.

Perhaps one of the more puzzling observations in the real world has been the appearance of clostridia and butyric acid in or near spoiled layers in silos. Given that clostridia are anaerobic bacteria, such observations seem to contradict logic. A recent study by Tabacco et al. (2009) adds some new information to help explain what may be happening. Maize and sorghum silages were made with (L. plantarum or L. buchneri) and without inoculant in 30 I silos. After $90 \mathrm{~d}$ ensiling, the silages were tested for aerobic stability and analysed for chemical and microbial changes after 0, 5, 7, 9 and $14 \mathrm{~d}$ aerobic exposure. In the maize silage, heating began after approximately $2 \mathrm{~d}$ in the untreated and L. plantarum treatments. At $5 \mathrm{~d}$, the $\mathrm{pH}$ was above 5.0 in these two treatments, but clostridial spore counts were approximately $2 \log _{10}$ (cfu g-1 silage). At $7 \mathrm{~d}$, the $\mathrm{pH}$ was above 6.5, temperatures were more than $20^{\circ} \mathrm{C}$ above ambient, and clostridial spore counts had risen to $>6 \log _{10}$ (cfu g-1 silage). Coincidentally nitrates in those treatments, which were at approximately $1000 \mathrm{mg} \mathrm{kg}^{-1}$ herbage at opening, had fallen linearly to undetectable levels by day 7. Nitrate content is indirectly related to inhibition of clostridia when reduced in anaerobic environments to nitrite (Pahlow et al. 2003). These results suggest that a combination of factors together are allowing clostridia to grow near spoiling layers: an increase in $\mathrm{pH}$ and temperature due to aerobic microorganisms, a return to anaerobic conditions due to spoilage microorganisms exhausting the oxygen supply closer to the oxygen source, and the utilization of nitrates that would normally inhibit clostridial growth under anaerobic conditions. This loss of nitrate suggests that enterobacteria (or possibly some LAB) may be proliferating prior to the clostridia because these bacteria are associated with nitrate reduction early in ensiling.

\section{Inoculants}

Microbial inoculants have become the dominant silage additive type in most parts of the world and have been available in many countries for decades. Until recently, most of these products were strains of facultative heterofermentative LAB (commonly called homofermenters) such as L. plantarum, L. casei, various Pediococcus species and Enterococcus faecium. The goal was to have a rapid and efficient fermentation that produced mostly lactic acid, minimizing DM losses and attempting to keep nutritive value similar to that of the crop at ensiling. The best of these products have not only enhanced silage fermentation and DM recovery but also improved animal performance: milk production, gain, feed efficiency (Weinberg and Muck 1996). However, these products have had a negative effect on aerobic stability in whole-crop maize and small grain silages, presumably because of the reduction in acetic acid. 
In the late 1990's, a new class of inoculants, based on obligate heterofermenters such as L. buchneri, entered the market. These strains grow slowly even after the active fermentation period is finished, producing acetic acid from sugars or lactic acid. The primary goal is to increase acetic acid so that yeast and mould growth is inhibited and aerobic stability is improved. However, these products appear to have limited effects on animal performance other than by keeping silage cool. Today we have a third class of inoculants that combine L. buchneri with more traditional strains attempting to get the DM recovery and animal performance of the facultative heterofermentative strains along with the aerobic stability improvements provided by L. buchneri.

There are many papers that report on the testing of various inoculants across a wide variety of forages. To review all of those studies properly is a manuscript by itself. Certainly this work is important in allowing scientists in various parts of the world to provide good recommendations to producers. However, from a more broad scientific perspective it is more interesting to understand why these products work and to look at current innovative efforts to find a new crop of inoculants.

\section{How inoculants dominate silage fermentation}

Recent studies are helping us understand why inoculants are often successful in the silo and how they may alter silage quality in a way that affects livestock response. The facultative heterofermentative LAB inoculant strains have been selected for rapid, homofermentative growth under a wide range of temperatures and DM concentrations. We expect that these strains will be highly competitive and produce largely lactic acid, reducing $\mathrm{pH}$ compared to an untreated silage with its mixture of obligate and facultative heterofermenters. However, there are a substantial number of incidences (e.g., Muck 1989) where the inoculant was applied at less than $10 \%$ of the epiphytic LAB population and still affected silage fermentation. Such instances suggest that at least some inoculant strains are not just faster but also have other competitive advantages over their fellow LAB as well as other epiphytic bacteria.

Some inoculant LAB strains produce antimicrobial compounds. Gollop et al. (2005) investigated whether 10 inoculants/commercial strains produced antibacterial activity. Nine of 10 inoculants when grown on MRS broth did produce compounds in the broth that inhibited the growth of Micrococcus luteus, a bacterial species susceptible to bacteriocins and other antibacterial compounds. Extracts of inoculated silages were also tested for inhibition of M. luteus. In 15 of 27 cases, the silage extracts from crop inoculated with one of the nine positive strains showed inhibition of $M$. luteus whereas none of the silage extracts from untreated control or the negative strain inhibited M. luteus (0 of 6 cases). Others (e.g., Marcinakova et al. 2005, Ratanapibulsawat et al. 2005) have isolated LAB strains from silage that produce inhibitory activity against a variety of bacterial species: Staphylococcus aureus, Salmonella sp., Bacillus sp., Listeria sp. and Escherichia coli.

Vazquez et al. (2005) studied the effects of bacteriocins from 6 strains of LAB (L. brevis, L. casei, L. helveticus, Lactococcus lactis, Leuconostoc mesenteroides, P. acidilactici) on the growth of those strains. The bacteriocin from a particular strain generally promoted the growth of that strain when added to the culture as well as increased bacteriocin production. When that bacteriocin was added to cultures of the other LAB strains, one would expect reduced growth. That was true particularly with the bacteriocins from $L$. brevis and $L c$. lactis. However, the $L$. $c a-$ sei and $L$. helveticus bacteriocins enhanced growth in the other five strains. Similarly bacteriocin production in one strain was most often reduced, but in some cases increased, by the presence of bacteriocin from another strain. The largest increase in bacteriocin production across species $(50 \%)$ was in $L$. casei when bacteriocins from $P$. acidilactici were added.

There is also evidence that some LAB produce antifungal compounds. Broberg et al. (2007) inoculated grass silage with two L. plantarum strains, one isolated from silage, that produce antifungal compounds in MRS broth. The antifungal compounds identified in laboratory culture, 3-phenyllactic acid and 3-hydroxydecanoic acid, were found at higher concentrations in the inoculated silages compared with those in the untreated silage. Other antifungal compounds, largely acids associated with lignin synthesis, were also elevated in the inoculated silages. It was not known what caused the increased concentrations of these compounds. Recently, Prema et al. (2010) also isolated a L. plantarum strain from grass silage that produced 3-phenyllactic acid and demonstrated that the acid inhibited a wide range of mould species common to silage.

These studies show that some LAB strains are capable of inhibiting a considerable spectrum of bacteria and fungi. The results of Gollop et al. (2005) indicate that it is relatively common to find antibacterial activity in inoculant strains. However, it is likely that much more could be done to select inoculant strains that are not only capable of dominating silage fermentation but also inhibiting undesirable anaerobic and aerobic microorganisms and so potentially reducing losses in quality and DM beyond that attained from an efficient fermentation. 


\section{How inoculants alter animal performance}

The effects of inoculants on gain or milk production in livestock have been greater than expected (Weinberg and Muck 1996). In fact, there are a significant number of reported cases where animal performance has been increased even though there was either no or only minor changes in $\mathrm{pH}$ or silage fermentation products. This is certainly intriguing. However, beyond scientific curiosity, improvements in animal performance provide a bigger return to the farmer than improvements in DM recovery. So there is incentive both scientifically and in helping farmers choose effective inoculants to understand how LAB silage inoculants affect livestock.

In some cases, there is an apparent linkage between changes in silage quality and animal performance. For example, Ando et al. (2006) found that guinea grass silage treated with L. rhamnosus had higher DM and organic matter digestibility and higher voluntary intake in wethers than untreated silage. When digestibility is improved, livestock should eat more if intake of the diet is limited by rumen fill. But we are still left wondering why an inoculant that consumes soluble portions of the crop should affect DM digestibility, which is primarily a function of the digestibility of insoluble structural polysaccharides.

In the past 10 years, we have begun to get important clues as to what may be happening at least with some inoculants. These clues point to changes occurring in the rumen of ruminant livestock. Weinberg et al. (2003) found that inoculant LAB could survive in rumen fluid, and some of the strains appeared to buffer $\mathrm{pH}$, keeping it from dropping as much as $\mathrm{pH}$ in unamended rumen fluid. Given that cellulolytic activity decreases at low rumen $\mathrm{pH}$, perhaps this may be a key to improved digestibility. Following up on these results, Muck et al. (2007) made silages using a wide range of inoculants. In vitro analysis was performed in serum bottles, measuring gas pressure. Surprisingly, some of the inoculated silages had reduced gas production compared with the untreated silages. Because digestibility has not been depressed by inoculants, these results suggested that in vitro fermentation was being shifted from gas production to another product - volatile fatty acids or rumen microorganisms.

Recent research has indicated that in vitro fermentation is altered by some inoculant strains. Cao et al. (2010) investigated the effect of a $L$. plantarum strain on an ensiled total mixed ration (TMR) based on whole crop rice. In vitro analysis of the inoculated TMR silage showed reduced methane production $(p=0.065)$ at 6 h of incubation compared with that of untreated TMR silage. Dry matter digestibility was not affected nor was the production of volatile fatty acids with the exception of butyrate being higher in the in vitro fermentation of the untreated silage. Cao et al. (2011) found similar results with the same inoculant strain in vegetable residue silage with the inoculated silage having the highest in vitro DM digestibility and lowest methane production. Contreras-Govea et al. (2011) performed in vitro analysis of maize and lucerne silages inoculated without or with one of four inoculants. While the inoculants produced only minor changes in silage fermentation, in vitro results were affected by treatment. At $9 \mathrm{~h}$ incubation, three of the four inoculated silages produced more microbial biomass yield as estimated by true minus apparent digestibility as compared with the untreated silages. At $48 \mathrm{~h}$, two of the inoculated silages had higher microbial biomass yield than the untreated silages. At both times, gas and volatile fatty acid production were not affected by treatment, and there were no inoculant by crop interactions. These results together suggest that some, but not all, inoculants are altering in vitro ruminal fermentation, whether by reduced methane production or increased microbial biomass production, in ways that should lead to increased animal performance.

One of the inoculants that increased microbial biomass yield in the Contreras-Govea et al. (2011) study was one with considerable published animal data (L. plantarum MTD/1), showing positive effects even in some cases where silage fermentation was not affected (Weinberg and Muck 1996). An animal trial has been performed to investigate whether this inoculant can improve rumen microbial biomass production (Muck et al. 2011). Milk production on inoculated lucerne silage was increased compared to the untreated silage. This was accompanied by a significant reduction in milk urea nitrogen that suggests better nitrogen utilisation and most likely more rumen microbial protein production. However, we are awaiting the results of the omasal samples to confirm that. Using ARISA to look at the rumen microbial community, we did not observe significant differences due to treatment, but real-time PCR did find elevated levels of L. plantarum in the rumens of cows on the treated silage (Mohammed et al. 2012).

Certainly there is considerably more research to be done in this area. Even if in the case of L. plantarum MTD/1 we can confirm that there is improved rumen microbial protein production that in turn explains increases in milk production, we still do not understand why that may be happening. Fortunately, it appears that in vitro analyses and our new PCR-based tools may be helpful in uncovering the secrets of how inoculation of silages by particular LAB strains affects silage utilisation by ruminants. 


\section{Strides to find new inoculants}

Most of the published efforts to develop new inoculant strains have been in Asia, South America and Africa. This might be expected. The major international companies producing inoculants are based in Europe and North America. So more of the inoculant research from these parts of the world is involved in testing commercial products. In addition, these products have been developed for cool-season grasses, whole-crop maize and lucerne, the dominant crops ensiled on those continents. These inoculants may or may not be as effective when used on warmseason grasses and tropical legumes.

One of the most complete, recently published screening procedures focused on identifying potential homofermentative strains with antimicrobial properties for ensiling cool-season grasses in Finland (Saarisalo et al. 2007). They began by selecting LAB strains from various sources, not just silages, based on antimicrobial activity against a wide range of microorganisms (coliforms, clostridia, Bacillus spp., Listeria spp., yeasts and moulds). Second, they grew the candidate strains on a grass extract medium, measuring fermentation products, growth rate, ammonia $\mathrm{N}$ and $\mathrm{pH}$. They also grew the strains on an API $50 \mathrm{CHL}$ test kit to determine the range of substrates each strain could ferment. They selected four strains that grew rapidly on a wide range of sugars, producing high levels of lactic acid, low $\mathrm{pH}$ and low ammonia $\mathrm{N}$. These four strains were then tested in a mini-silo trial with a timothymeadow fescue mixture and with silos being opened at 1, 3, 5, 7, 14, 21, 63 and $84 \mathrm{~d}$. Fermentation characteristics, gas production, and microbiological changes were measured. The ensiling trial confirmed the results of the grass extract screening. While they did not proceed further, additional winnowing of strains could be carried out, investigating the range of DM concentrations and temperatures under which the candidate strains could grow.

The approach that one takes in selecting strains depends upon the goals. In the Finnish research, the goal was to find a strain that could actively suppress non-LAB microbial species while producing an efficient fermentation largely of lactic acid and little breakdown of amino acids to ammonia. Similarly, Marcinakova et al. (2008) studied an E. faecium isolate that produces bacteriocins as a potential inoculant. More commonly the goal is to find species that rapidly and efficiently ferment sugars to lactic acid with little or no ammonia production. Recent such research includes for example: Penteado et al. (2007) in Panicum maximum silage, Kim et al. (2008) in whole-crop rice silage, Kim et al. (2009) in whole-crop barley silage, Yan et al. (2011) in maize silage.

Other goals depend upon the particular issues with a crop or its use. With sugar cane silage, the two major concerns are high ethanol concentrations and aerobic instability. Ávila et al. $(2009,2010)$ identified an L. buchneri strain that was better than commercial strains in reducing ethanol concentration and yeast counts while improving aerobic stability. In guinea grass silage, the targets for Pasebani et al. (2011) beyond low pH and ammonia were high crude protein and low fibre concentrations. Today, there can be alternate uses for silage as seen in the utilisation of silage to produce methane via anaerobic digestion. Banemann et al. (2010) investigated the potential of an inoculant to increase methane yield from maize silage. Consequently the selection goal will change the strain that will be most effective in the preservation or utilisation of a silage.

The most difficult target today is improvement in animal performance. Animal trials are expensive and time-consuming. This means that one has to narrow the field of candidates to two or three strains without having an effective measure to know how livestock will respond. Hopefully as we understand how inoculants affect animal performance we will be able to develop in vitro techniques that will allow us to more easily find strains that will be beneficial to livestock.

\section{Conclusions and future directions}

Over the past decade we have seen a marked increase in the use of PCR-based techniques in silage research. These techniques are greatly enhancing our ability to detect and monitor the species involved in ensiling. Often, common species like L. plantarum have been found across diverse crops and different continents, making it appear that perhaps we do not need to spend more time looking at the species in silages. In other cases such as with maize in warm climates, it appears that obligate heterofermenters such as Weissella and Leuconostoc species may play more significant roles than in temperate climates. This may or may not be significant to the utilisation of maize silage by livestock or the value of an inoculant. At this time, we do not know.

More studies of the microbial ecology of ensiling using these new PCR-based techniques are needed. Currently we have a limited number of snapshots of microbial dynamics over a wide variety of crops and locations. In some studies, not enough snapshots have been taken in the first week of ensiling to capture the dynamics when the 
major changes in fermentation products and $\mathrm{pH}$ are occurring. So we may be missing species that are keys to silage quality. We need to have more pictures of major silage crops in various locations so that we can build a global picture of whether those populations vary substantially by location or climate or not, and thus what inoculant characteristics may be most important.

The studies so far have primarily focused on ensiling under good conditions and on the spoilage of silages after silo opening. What would be of particular value is to better understand the microbial ecology of silage fermentations that go wrong. For example in the U.S., farmers occasionally get high acetic acid silages that have reduced intake, but other high acetic acid silages like those inoculated with L. buchneri are consumed at a level expected based on standard nutritive characteristics. The difference is likely the microbial species that produced the acetic acid, and the factor affecting intake is probably not acetic acid but some other product not measured. As we better understand the species that are causing such problems, we will be able to devise management strategies or additives to prevent those problems.

In concert with our ability to identify species in silage, we need to strive to do more than analyse for the major fermentation products. Some of the recent inoculant research discussed above has found various antimicrobial compounds at low levels, suggesting there are many minor compounds that may influence the course of fermentation in the silo and possibly rumen fermentation in cattle and other ruminants. There are concerns about volatile organic compounds coming from silages and their effect on the environment, and we need to understand whether those compounds are directly caused by microorganisms or indirectly by chemical interactions during storage. Metabolomics is just entering agricultural research (Ametaj et al. 2010) allowing us to identify many more minor compounds. It along with the PCR-based techniques may be keys to bringing us to a new level of understanding of what occurs in the silo and how these processes affect livestock and the environment. Armed with this new understanding, we will hopefully be able to improve the quality of the silage that we deliver to our livestock.

\section{Acknowledgements}

The author wishes to express his appreciation to F.E. Contreras-Govea and D.M. Stevenson in reviewing the manuscript.

\section{References}

Ametaj, B.N., Zebeli, Q., Saleem, F., Psychogios, N., Lewis, M.J., Dunn, S.M., Xia, J. \& Wishart, D.S. 2010. Metabolomics reveals unhealthy alterations in rumen metabolism with increased proportion of cereal grain in the diet of dairy cows. Metabolomics 6: 583-594.

Ando, S., Ishida, M., Oshio, S. \& Tanaka, O. 2006. Effects of isolated and commercial lactic acid bacteria on the silage quality, digestibility, voluntary intake and ruminal fluid characteristics. Asian-Australasian Journal of Animal Sciences 19: 386-389.

Ávila, C.L.S., Pinto, J.C., Figueiredo, H.C.P \& Schwan, R.F. 2009. Effects of an indigenous and a commercial Lactobacillus buchneri strain on quality of sugar cane silage. Grass and Forage Science 64: 384-394.

Ávila, C.L.S., Martins, C.E.C.B. \& Schwan, R.F. 2010. Identification and characterization of yeasts in sugarcane silages. Journal of Applied Microbiology 109: 1677-1686.

Banemann, D., Demmig, C., Nelles, M., Bock, P. \& Mayrhuber, E. 2010. Silages as feedstock for biogas: novel perspectives for silage additives, In: Jambor, V., Jamborova, S., Vosynkova, P., Prochazka, P., Vosynkova, D., Kumprechtova, D. (eds.). Conference Proceedings, 14th International Symposium Forage Conservation. Brno, Czech Republic. p. 114-116.

Borreani, G. \& Tabacco, E. 2010. The relationship of silage temperature with the microbiological status of the face of corn silage bunkers. Journal of Dairy Science 93: 2620-2629.

Broberg, A., Jacobsson, K., Strom, K. \& Schnurer, J. 2007. Metabolite profiles of lactic acid bacteria in grass silage. Applied and Environmental Microbiology 73: 5547-5552.

Brusetti, L., Borin, S., Mora, D., Rizzi, A., Raddadi, N., Sorlini, C. \& Daffonchio, D. 2006. Usefulness of length heterogeneity-PCR for monitoring lactic acid bacteria succession during maize ensiling. FEMS Microbiology Ecology 56: 154-164.

Brusetti, L., Borin, S., Rizzi, A., Mora, D., Sorlini, C. \& Daffonchio, D. 2008. Exploration of methods used to describe bacterial communities in silage of maize (Zea mays) cultivars. Environmental Biosafety Research 7: 25-33.

Cao, Y., Cai, Y., Takahashi, T., Yoshida, N., Tohno, M., Uegaki, R., Nonaka, K. \& Terada, F. 2011. Effect of lactic acid bacteria inoculant and beet pulp addition on fermentation characteristics and in vitro ruminal digestion of vegetable residue silage. Journal of Dairy Science 94: 3902-3912.

Cao, Y., Takahashi, T., Horiguchi, K., Yoshida, N. \& Cao, Y. 2010. Effect of adding lactic acid bacteria and molasses on fermentation quality and in vitro ruminal digestion of total mixed ration silage prepared with whole crop rice. Grassland Science 56: 19-25.

Contreras-Govea, F.E., Muck, R.E., Mertens, D.R. \& Weimer, P.J. 2011. Microbial inoculant effects on silage and in vitro ruminal fermentation, and microbial biomass estimation for alfalfa, bmr corn, and corn silages. Animal Feed Science and Technology 163: 2-10. 
Doi, K., Nishizaki, Y., Fujino, Y., Ohshima, T., Ohmomo, S. \& Ogata, S. 2009. Pediococcus lolii sp. nov., isolated from ryegrass silage. International Journal of Systematic and Evolutionary Microbiology 59: 1007-1010.

Dolci, P., Tabacco, E., Cocolin, L. \& Borreani, G. 2011. Microbial dynamics during aerobic exposure of corn silage stored under oxygen barrier or polyethylene films. Applied and Environmental Microbiology 77: 7499-7507.

Gollop, N., Zakin, V. \& Weinberg, Z.G. 2005. Antibacterial activity of lactic acid bacteria included in inoculants for silage and in silages treated with these inoculants. Journal of Applied Microbiology 98: 662-666.

Kim, J.G., Ham, J.S., Chung, E.S., Park, H.S., Lee, J.K., Jung, M.W., Choi, K.C., Cho, N.C. \& Seo, S. 2009. Evaluation of fermentation ability of microbes for whole crop barley silage inoculant. Journal of the Korean Society of Grassland and Forage Science 29: 235-244.

Kim, J.G., Ham, J.S., Chung, E.S., Yoon, S.H., Kim, M.J., Park, H.S., Lim, Y.C. \& Seo, S. 2008. Evaluation of fermentation ability of microbes for whole crop rice silage inoculant. Journal of the Korean Society of Grassland and Forage Science 28: 229-236.

Li, Y. \& Nishino, N. 2011a. Bacterial and fungal communities of wilted Italian ryegrass silage inoculated with and without Lactobacillus rhamnosus or Lactobacillus buchneri. Letters in Applied Microbiology 52: 314-321.

Li, Y. \& Nishino, N. 2011b. Monitoring the bacterial community of maize silage stored in a bunker silo inoculated with Enterococcus faecium, Lactobacillus plantarum and Lactobacillus buchneri. Journal of Applied Microbiology 110: 1561-1570.

Li, Y., Nishino, N. \& Li, Y.B. 2011. Effects of inoculation of Lactobacillus rhamnosus and Lactobacillus buchneri on fermentation, aerobic stability and microbial communities in whole crop corn silage. Grassland Science 57: 184-191.

Marcinakova, M., Laukova, A., Simonova, M., Strompfova, V., Korenekova, B. \& Nad, P. 2008. A new probiotic and bacteriocin-producing strain of Enterococcus faecium EF9296 and its use in grass ensiling. Czech Journal of Animal Science 53: 336-345.

Marcinakova, M., Simonova, M., Strompfova, V. \& Laukova, A. 2005. Occurrence of structural enterocin genes among silage enterococci. Bulletin of the Veterinary Institute in Puawy 49: 387-392.

McEniry, J., O'Kiely, P., Clipson, N.J.W., Forristal, P.D. \& Doyle, E.M. 2010. Assessing the impact of various ensilage factors on the fermentation of grass silage using conventional culture and bacterial community analysis techniques. Journal of Applied Microbiology 108: 1584-1593.

McEniry, J., O'Kiely, P., Clipson, N.J.W., Forristal, P.D. \& Doyle, E.M. 2008. Bacterial community dynamics during the ensilage of wilted grass. Journal of Applied Microbiology 105: 359-371.

Mohammed, R., Stevenson, D.M., Beauchemin, K.A., Muck, R.E. \& Weimer, P.J. 2012. Changes in ruminal bacterial community composition following feeding of alfalfa ensiled with a lactic acid bacterial inoculant. Journal of Dairy Science 95: 328-339.

Muck, R.E. 1989. Effect of inoculation level on alfalfa silage quality. Transactions of the ASAE 32: 1153-1158.

Muck, R.E., Broderick, G.A., Faciola, A.P. \& Hymes-Fecht, U.C. 2011. Milk production response to feeding alfalfa silage inoculated with Lactobacillus plantarum. Journal of Animal Science 89(E-Suppl 1): 546.

Muck, R.E., Filya, I. \& Contreras-Govea, F.E. 2007. Inoculant effects on alfalfa silage: In vitro gas and volatile fatty acid production. Journal of Dairy Science 90: 5115-5125.

Naoki, N. \& Yuji, T. 2008. Variations in bacterial communities in laboratory-scale and big bale silos assessed by fermentation products, colony counts and denaturing gradient gel electrophoresis profiles. Letters in Applied Microbiology 46: 283-288.

Pahlow, G., Muck, R.E., Driehuis, F., Oude Elferink, S.J.W.H. \& Spoelstra, S.F. 2003. Microbiology of ensiling, In: Buxton, D.R., Muck, R.E. \& Harrison, J.H. (eds.). Silage Science and Technology. Madison, Wisconsin, USA: American Society of Agronomy, Crop Science Society of America, Soil Science Society of America. p. 31-93.

Pang, H.L., Qin, G.Y., Tan, Z.F., Li, Z.W., Wang, Y.P. \& Cai, Y.M. 2011a. Natural populations of lactic acid bacteria associated with silage fermentation as determined by phenotype, $16 \mathrm{~S}$ ribosomal RNA and recA gene analysis. Systematic and Applied Microbiology 34: 235-241.

Pang, H.L., Zhang, M., Qin, G.Y., Tan, Z.F., Li, Z.W., Wang, Y.P. \& Cai, Y.M. 2011b. Identification of lactic acid bacteria isolated from corn stovers. Animal Science Journal 82: 642-653.

Parvin, S. \& Nishino, N. 2009. Bacterial community associated with ensilage process of wilted guinea grass. Journal of Applied Microbiology 107: 2029-2036.

Parvin, S. \& Nishino, N. 2010. Succession of lactic acid bacteria in wilted rhodesgrass silage assessed by plate culture and denaturing gradient gel electrophoresis. Grassland Science 56: 51-55.

Parvin, S., Wang, C., Li, Y. \& Nishino, N. 2010. Effects of inoculation with lactic acid bacteria on the bacterial communities of Italian ryegrass, whole crop maize, guinea grass and rhodes grass silages. Animal Feed Science and Technology 160: 160-166.

Pasebani, M., Yaakub, H., Alimon, A.R. \& Sijam, K. 2011. Effect of epiphytic lactic acid bacteria isolated from guinea grass on nutritional value of the silages. African Journal of Agricultural Research 6: 4447-4450.

Pauly, T.M. \& Spörndly, R. 2011. Minimum temperature for successful silage making. In: Zopollatto, M., Daniel, J.L.P., Nussio, L.G. \& Neto, A.d.S. (eds.). Il International Symposium on Forage Quality and Conservation in November in Sao Pedro, Brazil. Piracicaba: University of São Paulo. Summary 28.

Penteado, D.C.S., Santos, E.M., Carvalho, G.G.P.d., Oliveira, J.S.d., Zanine, A.M., Pereira, O.G., Ferreira, C.L.L.F., de Carvalho, G.G.P. \& de Oliveira, J.S. 2007. Lactobacillus plantarum from microbiota as inoculant for Panicum maximum silage. Archivos de Zootecnia 56: 191-202.

Prema, P., Smila, D., Palavesam, A. \& Immanuel, G. 2010. Production and characterization of an antifungal compound (3-phenyllactic acid) produced by Lactobacillus plantarum strain. Food and Bioprocess Technology 3: 379-386.

Ratanapibulsawat, C., Kroujkaew, P., Sadahiro, O., Nitisinprasert, S., Chatinan, R., Pumrussiri, K. \& Sunee, N. 2005. Screening and characterization of lactic acid bacteria producing antimicrobial substance against Staphylococcus aureus. Kasetsart Journal, Natural Sciences 39: 284-293. 
Rossi, F. \& Dellaglio, F. 2007. Quality of silages from Italian farms as attested by number and identity of microbial indicators. Journal of Applied Microbiology 103: 1707-1715.

Saarisalo, E., Skyttä, E., Haikara, A., Jalava, T. \& Jaakkola, S. 2007. Screening and selection of lactic acid bacteria strains suitable for ensiling grass. Journal of Applied Microbiology 102: 327-336.

Schmidt, R.J., Emara, M.G. \& Kung, L., Jr. 2008. The use of a quantitative real-time polymerase chain reaction assay for identification and enumeration of Lactobacillus buchneri in silage. Journal of Applied Microbiology 105: 920-929.

Stevenson, D.M., Muck, R.E., Shinners, K.J. \& Weimer, P.J. 2006. Use of real time PCR to determine population profiles of individual species of lactic acid bacteria in alfalfa silage and stored corn stover. Applied Microbiology and Biotechnology 71: 329-338.

Storm, I.M.L.D., Kristensen, N.B., Raun, B.M.L., Smedsgaard, J. \& Thrane, U. 2010. Dynamics in the microbiology of maize silage during whole-season storage. Journal of Applied Microbiology 109: 1017-1026.

Tabacco, E., Piano, S., Cavallarin, L., Bernardes, T.F. \& Borreani, G. 2009. Clostridia spore formation during aerobic deterioration of maize and sorghum silages as influenced by Lactobacillus buchneri and Lactobacillus plantarum inoculants. Journal of Applied Microbiology 107: 1632-1641.

Tabacco, E., Piano, S., Revello-Chion, A. \& Borreani, G. 2011. Effect of Lactobacillus buchneri LN4637 and Lactobacillus buchneri LN40177 on the aerobic stability, fermentation products, and microbial populations of corn silage under farm conditions. Journal of Dairy Science 94: 5589-5598.

Vazquez, J.A., Gonzalez, M.P. \& Murado, M.A. 2005. Stimulation of bacteriocin production by dialyzed culture media from different lactic acid bacteria. Current Microbiology 50: 208-211.

Villa, A.F., Melendez, A.P., Carulla, J.E., Pabon, M.L. \& Cardenas, E.A. 2010. Study of microbiological and nutritional quality of corn silage in two Colombian ecosystems. Revista Colombiana de Ciencias Pecuarias 23: 65-77.

Wang, P., Bai, C.S., Liu, L. \& Cao, B.H. 2011. Effects of lactic acid bacteria inoculant on the fermentation quality of reed grass (Phragmites australis Cav. Trin. ex Sterd.) at low temperature. Acta Agrestia Sinica 19: 127-131.

Wang, L.T., Kuo, H.P., Wu, Y.C., Tai, C.J. \& Lee, F.L. 2009. Lactobacillus taiwanensis sp. nov., isolated from silage. International Journal of Systematic and Evolutionary Microbiology 59: 2064-2068.

Weinberg, Z.G. \& Muck, R.E. 1996. New trends and opportunities in the development and use of inoculants for silage. FEMS Microbiology Reviews 19: 53-68.

Weinberg, Z.G., Muck, R.E. \& Weimer, P.J. 2003. The survival of silage inoculant lactic acid bacteria in rumen fluid. Journal of Applied Microbiology 94: 1066-1071.

Yan, P., Zhang, Y.H., Mairemunisa, A., Abudukeyoumu, M. \& Wusiman, Y. 2011. Isolation and identification of high-quality lactic acid bacteria in forage corn. Animal Husbandry and Feed Science 3: 7-10. 